\title{
IMPACT OF PREFORMED AND DE NOVO ANTI-HLA DP ANTIBODIES IN RENAL ALLOGRAFT SURVIVAL
}

Dolores Redondo-Pachón ${ }^{1}$, Julio Pascual ${ }^{1 *}$, María J. Pérez-Sáez ${ }^{1}$, Carmen García $^{2}$, Juan José Hernández ${ }^{2}$, Javier Gimeno ${ }^{3}$, Marisa Mir ${ }^{1}$, Marta Crespo ${ }^{1}$

${ }^{1}$ Department of Nephrology and Institute Mar for Medical Research, Hospital del Mar, Barcelona, Spain

${ }^{2}$ Laboratori de Referencia de Catalunya, Barcelona, Spain

${ }^{3}$ Department of Pathology, Hospital del Mar, Barcelona, Spain

*Corresponding author. Dr Julio Pascual. Department of Nephrology.

Passeig Maritim 25-29, 08003 Barcelona, Spain. Phone: +34932483162.

Email: jpascualsantos@parcdesalutmar.cat 


\section{ABSTRACT}

The influence of antibodies against HLA-DP antigens detected with solid-phase assays on graft survival after kidney transplantation (KT) is uncertain. We evaluated with Luminex ${ }^{\circledR}$ the prevalence of pre and postransplant DP antibodies in $440 \mathrm{KT}$ patients and their impact on graft survival. DP antibodies were present in $39.7 \% \mathrm{KT}$ with pretransplant HLA antibodies and $47.7 \%$ with DSA. Graft survival of KT with pretransplant class-II DSA was worse than with non-DSA $(p=0.01)$. DP antibodies did not influence graft survival. Of 346 patients monitored post-KT, $17.1 \%$ had HLA class-II antibodies, $56 \%$ with DP antibodies. Class-II DSA were detected in $39 \%, 60.9 \%$ of them had DP antibodies. Graft survival was worse in patients with class-II DSA ( $p=0.022)$. DP antibodies did not change these results. The presence of pretransplant and postransplant DSA is associated with a negative impact on graft survival. However, the presence of DP antibodies does not modify this impact significantly.

Keywords: renal transplant, HLA-DP antibodies, graft survival 


\section{INTRODUCTION}

One of the most relevant advances in organ transplantation has been the development of more sensitive assays to detect HLA antibodies, namely solidphase immunoassays in Luminex ${ }^{\circledR}$ platform [1-3]. Multiple studies have shown a correlation between the information derived from those new techniques and clinical events in renal allograft recipients [4-8]. Currently, Luminex ${ }^{\circledR}$ Single Antigen (LSA) studies permit the assessment of antibodies against antigens HLA A, B, C, DR, DQ and DP. Classically, HLA DP and HLA C have been considered to be less immunogenic than HLA A, B, DR and DQ molecules [9]. Two pairs of genes codify HLA DP molecules, two for region A and two for region B. Only one of these pairs of genes (DPA1 and DPB1) codify and a- and B-chains in each molecule, both showing many polymorphisms. The other pair of genes (DPA2 y DPB2) show a limited polymorphism, and the codified antigens are not expressed on cell surface. Until now, 132 alleles have been located in DPB1 exon 2, whereas 27 alleles are known for the less polymorphic DPA1 (DPA1*01-04) $[10,11]$.

The influence of HLA DP antibodies detected in Luminex ${ }^{\circledR}$ platform on short and long-term graft survival is not well-known. We aimed to evaluate their prevalence in renal allograft recipients before and after kidney transplantation (KT) and their impact on graft survival. 


\section{PATIENTS AND METHODS}

\subsection{Patients}

From January 2008 to March 2013, 440 renal allograft recipients transplanted between 1979 and 2012 and functioning for more than 3 months were included in the study. Transplantations were performed after negative CDC crossmatch. Internal review board approved the study. A database included demographics, donor type, number of previous transplantations, initial and maintenance immunosuppression, delayed or immediate graft function and acute rejection episodes. Graft function (serum creatinine, MDRD4 estimated glomerular filtration rate (GFR) and urinary protein/creatinine ratio) was recorded at the time of HLA antibody testing.

Pretransplant serum samples were available for 291 of the 440 patients included. A total of 346 patients had postransplant serum samples studied and follow-up was completed until March 2013.

\subsection{HLA antibodies determination and analyses}

Serum samples were stored at $-80^{\circ} \mathrm{C}$ until use. Anti-HLA antibodies detection was performed using Lifecodes-LifeScreen-Deluxe kits (Gen-Probe, Stanford, CT) in Luminex platform, according to manufacturer instructions. The kit comprised 7 beads with class-I glycoproteins and 5 with class-II glycoproteins. Three $\mu$ l of beads were incubated with $40 \mu$ of wash buffer and $12.5 \mu \mathrm{l}$ of pateint serum during 30 minutes and 3 washings were performed. Three $\mu$ of goat anti-human IgG conjugated to phycoerytrin o PE and $22 \mu \mathrm{l}$ of wash buffer in each well were incubated for 30 minutes. Samples were analyzed in 
Luminex 200 platform (Luminex, Austin, Tx) using Bio-Plex Manager 6.0 (software for data acquisition) and the program Matchlt!Antibody v1.1.0.2 (Gen-Probe) as software for analysis. A sample was considered to be positive for anti-HLA antibodies if: 1) at least one of the 7 beads with class-I and/or at least one of the 5 beads with class-II were positive with score $3 ; 2$ ) fulfilled established criteria for the negative internal control beads (CON1, 2 \& 3 ), and 3) showed an MFI for the positive control above 3500 . Also the kit's positive and negative control sera were included in each assay.

The identification of class-II specific IgG anti-HLA allo-antibodies was made with Lifecodes LSA ${ }^{\mathrm{TM}}$ Class-I and/or Clase-II kits (Gen-Probe), according to manufacturer instructions. The kit LSA Class-I included 93 beads with class-I HLA molecules (HLA-A , B, C), and the kit LSA Class-II included 84 beads with class-II HLA molecules (HLA-DR, DQ, DP). Data were analyzed using Matchlt! (Gen-Probe). The MFI cut-off point was set at 1000 for positivity.

The donor specificity of anti-HLA antibodies was considered with the typing of HLA A, B, DRB and in some cases for C y DQB. In case of unavailability of DQB and $\mathrm{C}$ typing, specificity was assigned through linkage desequilibrium.

\subsection{Statistical analysis}

Normal continuous variables are expressed with means and standard deviation (SD), and non-normal variables are expressed with median and interquartilic range (IQR). Chi-square tests were used for comparing categorical variables. Continuos variables were assessed using non-parametric Mann-Whitney $U$ tests or Student $\mathrm{t}$ tests depending on normality distribution. Survival analyses were performed using Kaplan-Meier curves with log-rank test comparisons. 
The multivariate analysis was performed using the logistic and Cox regression analysis.

The studies were perfomred using sofware SPSS v.21. Significance was considered with a $p<0.05$.

\section{RESULTS}

\subsection{Pretransplant antibodies}

\subsubsection{HLA DP antibodies in patients with pretransplant HLA antibodies}

Pretransplant sera were available in 291 of the $440 \mathrm{KT}$ recipients included in this study. HLA class-II IgG antibody screening was positive in 68 of them (23.3\%). Twenty-seven (39.7\%) had HLA DP antibodies in the LSA tests. Their characteristics compared with those patients with class-II positive screening but without HLA DP antibodies $(n=41)$ are shown in table 1 . Mean age in both groups was around 50 years, and they were predominantly women. Half of the patients had previously received another KT. Patients with HLA DP antibodies did not suffered biopsy-proven acute rejection episodes compared with $9.1 \%$ in the group of patients with pretransplant HLA class-II antibodies without DP specificities.

3.1.2. HLA DP antibodies in patients with pretransplant donor-specific anti-HLA antibodies (DSA) 
Among the 68 patients who screened positive for HLA class-II antibodies, 36 (52.9\%) had DSA. In 47.2\% patients with DSA, we found HLA DP antibodies, while this percentage was only $31.2 \%$ in those patients with HLA non-DSA.

In the group of patients with DSA no clinical or demographical differences were found among patients with HLA DP antibodies and those with HLA without DP antibodies, although the rate of delayed graft function was higher in patients with HLA DP antibodies $(61,9 \%$ vs $13,3 \%, \quad p=0.005)$. However, a multivariate analysis adjusted for donor age and cold ischemia time, made this significant difference in DGF to dissapear $(p=0,14$; IC 95\% 0,2-42,5). The incidence of biopsy-proven acute rejection according to Banff 2009 classification was numerically but not significantly higher in the group of patients with HLA DP antibodies. They were T cell-mediated (Banff 4 category), except for two acute humoral rejection episodes (Banff 2 category) (one in a patient with HLA DP antibodies and one in a recipient without HLA DP antibodies).

Available donor DNA permitted typing for DP in 7 cases with pretransplant antibodies: for 5 patients in the group with HLA non DSA, DP antibodies resulted to be non donor-specific and none of them presented acute humoral rejection (graft survival: $100 \%$ ). The remaining two recipients with available donor DP typing resulted to have DP DSA, besides DQ and DR DSA; both presented antibody mediated rejection.

\subsubsection{Characteristics of DP antibodies}

Median MFI of HLA DPB1* antibodies was similar in those with DSA and without DSA (3623 [IQR: 2067-15.736] vs 3672 [IQR: 1683-7279]). The most frequently 
detected DPB1* specificity was DPB ${ }^{*} 05: 01$, in $18.5 \%$ patients. In the subgroup with DSA, the most frequent specificity was DPB1*04:02 and in those with HLA non-DSA, it was DPB1*02:01. The distribution of specificities is depicted in Figure 1A. Analysis of DP epitopes in patients with pretransplant DP antibodies showed that 84DEAV was the most frecuent $(19,5 \%)$, followed by $35 \mathrm{LV}$ (14,6\%); and 127L, 55DE and 84 VG were present in $9,8 \%$ of the patients.

All 27 patients with pretransplant anti HLA DP antibodies had prior sensitizing events (51.8\% prior transplant, 26\% blood transfusion and 24\% pregnancy). We could not find any correlation between a specific sensitizing event and different epitopes.

In addition to HLA DP antibodies, other specificities were detected in $90 \%$ of patients (Figure 2B). Only 3 patients had isolated HLA DP antibodies before KT. None of them had a sensitizing event (male, no previous transplantation and no blood transfusions). The median (IQR) MFI was 3059 (1937-3590). After KT, they did not show these DP antibodies. At follow up, graft survival was $100 \%$, and none of them sufferedacute rejection episode.

\subsubsection{Impact of pretransplant HLA DP antibodies on graft survival}

Patients with pretransplant DSA showed worse censored-for-death graft survival than those with anti-HLA non-DSA $(p=0.01)$ after a median follow-up of 76.5 months (IQR 35-149.7). The presence or absence of HLA DP antibodies did not affect graft survival in patients with DSA $(p=0.54)$ and with HLA nonDSA (Figure 2). 
A Cox regression analysis adjusted for retransplantation, recipient gender and pretransplant CDC PRA showed similar survival in patients with DSA despite the presence of HLA DP antibodies before kidney transplantation (Table 3).

\subsection{Postransplant antibodies}

\subsubsection{HLA DP antibodies in patients with postransplant HLA antibodies}

The analysis of postransplant antibodies in 346 patients showed that 59 (17.1\%) had a positive screening for HLA class-II IgG antibodies. Thirty-three of them (56\%) with HLA DP antibodies. When we compared patients with HLA DP antibodies $(n=33)$ and those without $(n=26)$, there were no differences in age, gender, type of donor, retransplantation, HLA mismatches and pretransplant sensitization (table 2). Biopsy-proven acute rejection rate was similar in both groups, being all T cell-mediated. No significant differences were detected in the proportion of patients with pretransplant DSA between those with postransplant HLA DP antibodies and patients without HLA DP antibodies (42.4 vs $35.6 \%, \mathrm{p}=0,81))$.

\subsubsection{HLA DP antibodies in patients with postransplant DSA}

Postransplant assessment evidenced DSA in 23 patients (39\%). The presence of HLA DP antibodies in this group was $60.9 \%$ vs $52,8 \%$ in patients with anti-HLA non-DSA.

\subsubsection{Characteristics of postransplant DP antibodies}


Postransplant HLA DP antibodies showed a median MFI of 3116 (1814-4322). The most frequent DPB1* specificities were DPB1*17:01 $(21,2 \%)$ followed by DPB1*13:01 and DPB1*18:01, present in $18.2 \%$ of patients. Similarly to pretransplantation, in most patients $(91 \%)$ the presence of HLA DP antibodies was associated with other anti-HLA class-II DR and/or DQ specificities (Figura 3A). Only 3 patients had isolated HLA DP antibodies. In 2 cases, they appeared de novo after trasplantation. At the end of follow-up, those 3 patients had a functioning graft and had not suffered rejection episodes. Median anti-HLA DP MFI values was similar in patients with DSA and patients with anti-HLA nonDSA [2435 (1718-3869) vs 2650 (1654-4289), respectively]. De novo postransplant HLA DP antibodies were detected in 5 patients with DSA and 8 patients without DSA. In 6 patients we could not confirm the de novo appearance, as pretransplant sera were not available (Figure 3B).

Analysis of DP epitopes revealed that 84DEAV was the most common target postransplantation being present in $19 \%$ of patients with DP antibodies, same as before kidney transplantation. Epitopes 8V, 76I, 55DE and 35FV were detected in $14,3 \%$ patients respectively.

\subsubsection{Impact of postransplant HLA DP antibodies on graft survival}

Death-censored graft survival was better in patients without DSA after a median follow-up of $48(35-50,7)$ months $(p=0.022)$ after HLA antibody testing. The presence of HLA DP antibodies did not modify the impact on graft-survival. Patients with DSA with or without HLA DP antibodies showed comparable graft survival $(p=0.34)$. Similarly, among those patients with nonDSA HLA antibodies, patients with and without HLA DP antibodies did not 
show differences in graft survival at the end of follow-up ( $p=0.50)$ (Figure 4). A Cox regression analysis adjusted for retransplantation, receptor gender and pretransplant CDC PRA showed no differences in graft survival between patients with DSA with or without HLA DP after the transplant (Table 3).

\section{DISCUSSION}

In our experience, the prevalence of Luminex $^{\circledR}$ detected anti-HLA DP antibodies is similar before and after KT (9.2\% vs $9.5 \%$ respectively). However, the prevalence of isolated anti-HLA DP is very low. Only 3 patients before and 3 patients after KT showed those antibodies without any other class-II specificities ( $1 \%$ vs $0.9 \%$ respectively). In our study, $53 \%$ of patients with pretransplant anti-HLA antibodies had DSA, and almost half of them anti-HLA DP. In the postransplant study, $39 \%$ of patients showed DSA, $60 \%$ of them being anti-HLA DP. We cannot provide information of weather these anti-HLA DP antibodies are against the donor. Our results suggest that these antibodies do not impact graft survival, neither in patients with DSA nor in those without DSA. Consequently, it is possible that the assessment of anti-HLA DP specificities would only be necessary in selected cases, for instance in those with suspicion of humoral rejection and apparently negative DSA.

Before LSA assessments became common practice, clinical studies including the detection of HLA DP antibodies were scarcely reported. Technical complexity for the detection of such antibodies with lymphocytotoxicity probably explains this fact. In the most relevant pre-Luminex study, the presence of HLA DP antibodies in sera from 505 patients included in a waiting 
list for KT showed a prevalence of 7.3\% [12].

Despite the fact that solid-phase immunoassays allow precise detection of HLA antibodies, only few studies have reported their data on Luminex detected HLA DP antibodies. One of the first studies assessed 738 waitlisted patients with FlowPRA ${ }^{\circledast}$ beads. Anti-HLA class-II antibodies were detected in $23.1 \%$ of patients, a similar proportion to ours (23.3\%) [13]. In this series of KT candidates, $12 \%$ of patients showed HLA DP antibodies. Two additional studies using Luminex ${ }^{\circledR}$ beads showed similar pretransplant prevalences $[11,14]$.

The postransplant impact of the presence of HLA DP antibodies has been even less frequently reported. Before the development of solid-phase assays, a large study in more than 3600 patients receiving a deceased-donor primary KT evaluated the influence of mismatches in HLA DPB locus in one-year graft survival. No differences were observed when comparing all patients with 0,1 or 2 DPB mismatches [15]. The increased number of DPB mismatches only showed a negative influence in graft survival in the subgroup of 1305 retransplantations: the $345 \mathrm{KT}$ recipients without DPB mismatches, showed one-year graft survival of $83 \%$, significantly better than those with 1 or 2 mismatches. In a later study, undertaken with Luminex platform, the presence of HLA DP antibodies was more frequent inpatients with graft rejection $(19,5 \%$ vs $5,1 \%, p<0,001)$, though the impact on survival was not reported [16].

Numerous studies have demonstrated that the presence of DSA, both pre- and postransplantation is associated with a negative impact on renal allograft survival [17-20]. Our results confirm this negative impact, both for pre- and 
postransplant DSA. Donor HLA DP typing is not usually performed, and consequently, it is difficult to know whether or not the IgG antibodies detected with single antigen studies are directed specifically against the donor antigens. As a result, the potential clinical relevance, the relationship with humoral rejection, and the impact on graft survival are not easy to assess, as it has more easily been analyzed for class-II anti-HLA DR and DQ [21-23]. Only one report evaluated the impact of the presence of DSA against HLA DP compared with anti-HLA DP non-DSA. Three of 6 patients with pretransplant donor-specific anti-HLA DP, without any other DSA, developed antibody-mediated rejection, compared with only 1 of 15 patients with non donor specific anti-HLA DP $(p=0,02)$. The main concern of this latter study, in addition to the low number of patients, is that no data was reported on the impact of humoral rejection on graft survival or graft loss [24]. Other authors have described isolated cases of antibody-mediated rejection in patients with donor specific HLA DP antibodies without other DSA [25-27].

The main limitation of our study is the absence of information regarding donor HLA-DP typing, resulting in the impossibility of identifying true donorspecificity of anti-HLA DP antibodies. Besides, patients were included in the study only if their kidney grafts survived over three months. LSA tests were not performed for all patients included in the study but only for those who had a positive HLA class-II screening result before or after transplantation, thus assuming sera which screened negative should not show DP antibodies. 


\section{CONCLUSIONS}

In our population, approximately $10 \%$ of $\mathrm{KT}$ recipients show anti-HLA DP antibodies in single antigen studies, both pre- and postransplantation. The presence of pretransplant and postransplant DSA are both associated with a negative impact on graft survival. However, the presence of HLA DP antibodies does not modify this impact significantly. Nevertheless, DP antibodies have been identified in cases of antibody-mediated rejection. In selected cases of humoral rejection with undetected HLA A, B, DR or DQ DSA, HLA DP antibodies, as well as other non-HLA antibodies, should be assesed. Larger studies with KT donors well typed for HLA DP are needed to confirm our results.

\section{ACKNOWLEDGEMENTS}

We are indebted to Sara Alvarez, Anna Faura and all the study coordinators and nurse staff for their contribution.

Authorship: DRP, JP and MC designed research the study, performed the study, analyzed data and wrote the paper; CG and JJH performed the antibody tests; JG did the pathology studies; MJPS and MM collected data. All authors reviewed the manuscript draft and approved the final version. Funding sources: This study was performed with funding from the projects PI10/01370, PI13/00598 Spanish Ministry of Health ISCIII FIS-FEDER, Marato TV3 137/C/2012 and RedinRen RD12/0021/0024. 


\section{REFERENCES}

[1] Pei R, Lee JH, Shih NJ, Chen M, Terasaki PI. Single human leukocyte antigen flow cytometry beads for accurate identification of human leukocyte antigen antibody specificities. Transplantation 75 (2003) 43-9.

[2] Mizutani K, Terasaki P, Hamdani E et al. The importance of anti-HLAspecific antibody strength in monitoring kidney transplant patients. Am J Transplant 7 (2007) 1027-31.

[3] Tait BD, Süsal C, Gebel HM et al. Consensus guidelines on the testing and clinical management issues associated with HLA and non-HLA antibodies in transplantation. Transplantation 95 (2013) 19-47.

[4] Lefaucheur C, Loupy A, Hill GS et al. Preexisting donor-specific HLA antibodies predict outcome in kidney transplantation. J Am Soc Nephrol 21 (2010) 1398-406.

[5] Gloor JM, Winters JL, Cornell LD et al. Baseline donor-specific antibody levels and outcomes in positive crossmatch kidney transplantation. Am. J. Transplant 10 (2010) 582-589.

[6] Wiebe C, Gibson IW, Blydt-Hansen TD et al. Evolution and clinicalpathologic correlations of de novo donor-specific HLA antibody post kidney transplant. Am J Transplant 12 (2012) 1157-67.

[7] Loupy A, Hill GS, Jordan SC. The impact of donor-specific anti-HLA antibodies on late kidney allograft failure. Nat Rev Nephrol 8 (2012) 348-57.

[8] Everly MJ, Rebellato LM, Haisch CE et al. Incidence and impact of de novo donor-specific alloantibody in primary renal allografts. Transplantation 91 (2013) 410-7.

[9] Gilbert M, Paul S, Perrat G et al. Impact of pretransplant human leukocyte antigen-C and -DP antibodies on kidney graft outcome. Transplant Proc 43 (2011) 3412-4.

[10] Versluis LF, Rozemuller E, Tonks S et al. High-resolution HLA-DPB typing based upon computerized analysis of data obtained by fluorescent sequencing of the amplified polymorphic exon 2.Hum Immunol. 38 (1993) 277-83.

[11] Billen EV, Christiaans MH, Doxiadis II, Voorter CE, Berg-Loonen EM. HLADP antibodies before and after renal transplantation. Tissue Antigens. 75 (2010) 278-85.

[12] Pfeiffer K, Vögeler U, Albrecht KH, Eigler FW, Buchholz B, Grosse-Wilde $\mathrm{H}$. HLA-DP antibodies in patients awaiting renal transplantation. Transpl Int 8 (1995) 180-4. 
[13] Youngs D. HLA-DP Alloantibodies. ASHI Quarterly (2004) 60-2.

[14] Ling M, Marfo K, Masiakos $\mathrm{P}$ et al. Pretransplant anti-HLA-CW and antiHLA-DP antibodies in sensitized patients. Hum Immunol 73 (2012) 879-83.

[15] Mytilineos J, Deufel A, Opelz G. Clinical relevance of HLA-DPB locus matching for cadaver kidney retransplants: a report of the Collaborative Transplant Study. Transplantation 63 (1997) 1351-4.

[16] Qiu J, Cai J, Terasaki PI, El-Awar N, Lee JH. Detection of antibodies to HLA-DP in renal transplant recipients using single antigen beads. Transplantation 80 (2005) 1511-3.

[17] Caro-Oleas JL, González-Escribano MF, Gentil-Govantes MA et al. Clinical relevance of anti-HLA donor-specific antibodies detected by Luminex assay in the development of rejection after renal transplantation. Transplantation 94 (2012) 338-44.

[18] Lachmann N, Terasaki PI, Budde K et al. Anti-human leukocyte antigen and donor-specific antibodies detected by luminex posttransplant serve as biomarkers for chronic rejection of renal allografts. Transplantation 87 (2009) 1505-13.

[19] Crespo M, Torio A, Mas V al. Clinical relevance of pretransplant anti-HLA donor-specific antibodies: does C1q-fixation matter? Transpl Immunol 29 (2013) 28-33.

[20] Loupy A, Lefaucheur C, Vernerey D et al. Complement-binding anti-HLA antibodies and kidney-allograft survival. N Engl J Med 369 (2013) 1215-26.

[21] DeVos JM, Gaber AO, Knight RJ et al. Donor-specific HLA-DQ antibodies may contribute to poor graft outcome after renal transplantation. Kidney Int 82 (2012) 598-604.

[22] Willicombe $M$, Brookes $P$, Sergeant $R$ et al. De novo DQ donor specific antibodies are associated with a significant risk of antibody-mediated rejection and transplant glomerulopathy. Transplantation 94 (2012) 172-177.

[23] Wiebe C, Pochinco D, Blydt-Hansen TD et al. Class II HLA epitope matching-A strategy to minimize de novo donor specific antibody development and improve outcomes. Am J Transplant 13 (2013) 3114-22.

[24] Jolly EC, Key $\mathrm{T}$, Rasheed $\mathrm{H}$ et al. Preformed donor HLA-DP-specific antibodies mediate acute and chronic antibody-mediated rejection following renal transplantation. Am J Transplant 12 (2012) 2845-8.

[25] Goral S, Prak EL, Kearns J et al. Preformed donor-directed anti-HLA-DP antibodies may be an impediment to successful kidney transplantation. Nephrol Dial Transplant 23 (2008) 390-2. 
[26] Thaunat O, Hanf W, Dubois Vet al. Chronic humoral rejection mediated by anti-HLA-DP alloantibodies: insights into the role of epitope sharing in donor-specific and non-donor specific alloantibodies generation. Transpl Immunol 20 (2009) 209-11.

[27] Singh P, Colombe BW, Francos GC, Martinez Cantarin MP, Frank AM. Acute humoral rejection in a zero mismatch deceased donor renal transplant due to an antibody to an HLA-DP alpha. Transplantation 90 (2010) 220-1. 
Table 1. Demographic and clinical characteristics of studied patients distributed according to the presence or absence of donor-specific antibodies (DSA) and the presence or absence of HLA DP antibodies before kidney transplantation.

\begin{tabular}{|c|c|c|c|c|c|c|c|}
\hline & \multirow{2}{*}{$\begin{array}{c}\text { No } \\
\text { antibodies } \\
(\mathrm{n}=223)\end{array}$} & \multicolumn{2}{|c|}{ Anti-HLA no DSA $(n=32)$} & \multirow[b]{2}{*}{$\mathrm{p}$} & \multicolumn{2}{|c|}{ DSA $(n=36)$} & \multirow[b]{2}{*}{$\mathrm{p}$} \\
\hline & & $\begin{array}{l}\text { HLA DP } \\
\text { antibodies } \\
(n=10)\end{array}$ & $\begin{array}{l}\text { No HLA DP } \\
\text { antibodies } \\
(n=22)\end{array}$ & & $\begin{array}{c}\text { HLA DP } \\
\text { antibodies } \\
(n=17)\end{array}$ & $\begin{array}{l}\text { No HLA DP } \\
\text { antibodies } \\
\quad(n=19)\end{array}$ & \\
\hline $\begin{array}{l}\text { Recipient age } \\
\text { (years, mean } \pm S D \text { ) }\end{array}$ & $\begin{array}{c}52,5 \\
( \pm 14,5)\end{array}$ & $\begin{array}{c}49,2 \\
( \pm 15,2)\end{array}$ & $\begin{array}{c}48,8 \\
( \pm 13,3)\end{array}$ & 0,86 & $\begin{array}{c}52,3 \\
( \pm 14,03)\end{array}$ & $\begin{array}{c}46,4 \\
( \pm 10,2)\end{array}$ & 0,95 \\
\hline Female recipient (\%) & $32,1 \%$ & $42,9 \%$ & $64,7 \%$ & 0,19 & $66,7 \%$ & $64,7 \%$ & 1 \\
\hline Deceased donor (\%) & $91,1 \%$ & $92,9 \%$ & $100 \%$ & 0,45 & $95,2 \%$ & $93,3 \%$ & 0,34 \\
\hline Retransplantation (\%) & $8 \%$ & $20 \%$ & $13,6 \%$ & 0,67 & $71,4 \%$ & $80 \%$ & 0,70 \\
\hline Peak PRA CDC>5\% (\%) & $11,7 \%$ & $28,6 \%$ & $17,6 \%$ & 0,61 & $42,9 \%$ & $40 \%$ & 0,86 \\
\hline $\begin{array}{l}\text { Pretransplant PRA } \\
\text { CDC>5\% (\%) }\end{array}$ & $1 \%$ & 0 & 0 & - & $26,7 \%$ & $23,5 \%$ & 0,57 \\
\hline $\begin{array}{l}\text { HLA A/B/DR mismatch } \\
(\text { mean } \pm S D)\end{array}$ & $\begin{array}{c}4,1 \\
( \pm 1,2)\end{array}$ & $\begin{array}{c}4 \\
( \pm 1,1)\end{array}$ & $\begin{array}{c}3,9 \\
( \pm 1,2)\end{array}$ & 0,89 & $4,4( \pm 0,9)$ & $\begin{array}{c}3,6 \\
( \pm 1,6)\end{array}$ & 0,19 \\
\hline $\begin{array}{l}\text { Delayed graft function } \\
(\%)\end{array}$ & $37,9 \%$ & $42,9 \%$ & $23,5 \%$ & 0,45 & $61,9 \%$ & $13,3 \%$ & 0,005 \\
\hline $\begin{array}{l}\text { Acute rejection (\%) } \\
\text { (ACR/AHR/Borderline) }\end{array}$ & $\begin{array}{c}7,2 \% \\
(8 / 2 / 6)\end{array}$ & $0 \%$ & $\begin{array}{c}9,1 \% \\
(2 / 0 / 0)\end{array}$ & - & $\begin{array}{l}23,5 \% \\
(2 / 1 / 1)\end{array}$ & $\begin{array}{c}5,2 \% \\
(0 / 1 / 0)\end{array}$ & 0,29 \\
\hline \multicolumn{8}{|l|}{ DSA class I (n, \%) } \\
\hline $\begin{array}{l}\text { Only class I } \\
\text { Class I and II }\end{array}$ & $\begin{array}{c}4(1,7 \%) \\
0\end{array}$ & $\begin{array}{l}0 \\
0\end{array}$ & $\begin{array}{l}0 \\
0\end{array}$ & - & $\begin{array}{c}0 \\
4(23,5 \%)\end{array}$ & $\begin{array}{c}0 \\
2(10,5 \%)\end{array}$ & 0,99 \\
\hline $\begin{array}{l}\text { Follow-up after KT } \\
\text { [months: median } \\
(\mathrm{IQR})]\end{array}$ & $\begin{array}{c}45 \\
(26-66)\end{array}$ & $\begin{array}{c}56 \\
(28-97)\end{array}$ & $\begin{array}{c}80 \\
(52-103)\end{array}$ & 0,22 & $\begin{array}{c}66 \\
(40-86)\end{array}$ & $\begin{array}{c}47 \\
(23-82,5)\end{array}$ & 0,21 \\
\hline
\end{tabular}


Table 2. Demographic and clinical characteristics of studied patients distributed according to the presence or absence of donor-specific antibodies (DSA) and the presence or absence of HLA DP antibodies after kidney transplantation.

\begin{tabular}{|c|c|c|c|c|c|c|c|}
\hline & & Anti-HLA r & DSA $(n=36)$ & & DS & $(n=23)$ & \\
\hline & $\begin{array}{l}\text { antibodies } \\
(\mathrm{n}=287)\end{array}$ & $\begin{array}{c}\text { HLA DP } \\
\text { antibodies } \\
(n=19)\end{array}$ & $\begin{array}{l}\text { No HLA DP } \\
\text { antibodies } \\
\quad(n=17)\end{array}$ & $\mathrm{p}$ & $\begin{array}{l}\text { HLA DP } \\
\text { antibodies } \\
(n=14)\end{array}$ & $\begin{array}{l}\text { No HLA DP } \\
\text { antibodies } \\
\qquad(n=9)\end{array}$ & $\mathrm{p}$ \\
\hline $\begin{array}{l}\text { Recipient age } \\
\text { (years, mean } \pm \text { SD) }\end{array}$ & $\begin{array}{c}48,8 \\
( \pm 14,2)\end{array}$ & $\begin{array}{c}50,1 \\
( \pm 14,9)\end{array}$ & $\begin{array}{c}48,9 \\
( \pm 15,6)\end{array}$ & 0,98 & $\begin{array}{c}48,1 \\
( \pm 12,2)\end{array}$ & $\begin{array}{c}48,3 \\
( \pm 12,4)\end{array}$ & 0,96 \\
\hline Female recipient (\%) & $34,1 \%$ & $66,9 \%$ & $56,5 \%$ & 0,29 & $60 \%$ & $61,9 \%$ & 0,94 \\
\hline Deceased donor (\%) & $91,6 \%$ & $100 \%$ & $100 \%$ & - & $100 \%$ & $84,6 \%$ & 0,43 \\
\hline Retransplantation (\%) & $9,4 \%$ & $23,1 \%$ & $47,8 \%$ & 0,14 & $60 \%$ & $61,5 \%$ & 0,92 \\
\hline Peak PRA CDC>5\% (\%) & $12 \%$ & $23,1 \%$ & $26,1 \%$ & 0,84 & $30 \%$ & $61,5 \%$ & 0,21 \\
\hline $\begin{array}{l}\text { Pretransplant PRA } \\
C D C>5 \%(\%)\end{array}$ & $1,8 \%$ & 0 & 0 & - & 0 & $13,3 \%$ & 0,07 \\
\hline $\begin{array}{l}\text { HLA A/B/DR mismatch } \\
(\text { mean } \pm S D)\end{array}$ & $\begin{array}{c}3,7 \\
( \pm 1,4)\end{array}$ & $\begin{array}{c}4,1 \\
( \pm 0,98)\end{array}$ & $\begin{array}{l}3,04 \\
( \pm 1,5)\end{array}$ & 0,02 & $\begin{array}{c}3,9 \\
( \pm 1,1)\end{array}$ & $\begin{array}{c}3,9 \\
( \pm 1,2)\end{array}$ & 0,19 \\
\hline $\begin{array}{l}\text { Delayed graft function } \\
\text { (\%) }\end{array}$ & $41,4 \%$ & $53,8 \%$ & $47,8 \%$ & 0,83 & $50,1 \%$ & $53,6 \%$ & 0,85 \\
\hline $\begin{array}{l}\text { Acute rejection (\%) } \\
\text { (ACR/AHR/Borderline) }\end{array}$ & $\begin{array}{c}5,9 \% \\
(9 / 2 / 6)\end{array}$ & 0 & $\begin{array}{l}23,5 \% \\
(3 / 0 / 1)\end{array}$ & - & $\begin{array}{c}14,3 \% \\
(0 / 2 / 0)\end{array}$ & $\begin{array}{l}22,2 \% \\
(2 / 0 / 0)\end{array}$ & 0,59 \\
\hline Pretransplant DSA (\%) & $6,8 \%$ & $44,1 \%$ & $46,6 \%$ & 0,91 & $83,3 \%$ & $85,7 \%$ & 0,97 \\
\hline $\begin{array}{l}\text { Postransplant DSA class I } \\
\text { (n, \%) } \\
\text { Only class I } \\
\text { Class I and II }\end{array}$ & $\begin{array}{c}2(0,7 \%) \\
0\end{array}$ & $\begin{array}{l}0 \\
0\end{array}$ & $\begin{array}{c}1(5,9 \%) \\
0\end{array}$ & - & $\begin{array}{l}0 \\
0\end{array}$ & $\begin{array}{l}0 \\
0\end{array}$ & - \\
\hline $\begin{array}{l}\text { Follow-up after HLA test } \\
\text { [months: median (IQR)] }\end{array}$ & $\begin{array}{c}48 \\
(40-51)\end{array}$ & $\begin{array}{c}48 \\
(29-52)\end{array}$ & $\begin{array}{c}47 \\
(44-51)\end{array}$ & 0,61 & $\begin{array}{c}45,5 \\
(30-48)\end{array}$ & $\begin{array}{c}29 \\
(26-34)\end{array}$ & 0,87 \\
\hline
\end{tabular}


Table 3. Cox regression analysis before and after transplantation comparing DSA patients with and without HLA DP antibodies

\begin{tabular}{|c|c|c|c|c|}
\hline & & \multirow{2}{*}{\multicolumn{3}{|c|}{ Pre-transplantation }} \\
\hline & & & & \\
\hline & HR & \multicolumn{2}{|c|}{ IC $95 \%$} & $\mathrm{p}$ \\
\hline Retransplantation & 1,59 & 0,18 & 13,8 & 0,67 \\
\hline Female recipient & 1,05 & 0,097 & 11,39 & 0,96 \\
\hline \multirow[t]{3}{*}{ Pretransplant PRC CDC } & 0,99 & 0,93 & 1,05 & 0,81 \\
\hline & & \multicolumn{3}{|c|}{ Post-transplantation } \\
\hline & HR & \multicolumn{2}{|c|}{ IC $95 \%$} & $\mathrm{p}$ \\
\hline Retransplantation & 1.14 & 0,16 & 7,81 & 0,892 \\
\hline Female recipient & 1,26 & 0,12 & 12,66 & 0,842 \\
\hline Pretransplant PRC CDC & 1,04 & 0,95 & 1,061 & 0,890 \\
\hline
\end{tabular}




\section{Figure legends}

Figure 1 (A) Pretransplant HLA-DP antibodies specificities (B) Detection of DP antibodies and other HLA clase II antibodies (DR, DQ).

Figure 2 Kidney Allograft Survival acording to donor specific antibodies (DSA) and antiHLA DP antibodies detected pretransplantation.

Figure 3 (A) Detection of DP antibodies and other HLA clase II antibodies (DR, DQ). (B) Preformed and de novo antiHLA-DP antibodies in patients with donor specific antibodies (DSA) and non-donor specific antibodies (HLA non-DSA).

Figure 4 Kidney Allograft Survival acording to donor specific antibodies (DSA) and antiHLA DP antibodies detected postransplantation. 
Figure 1

(A)

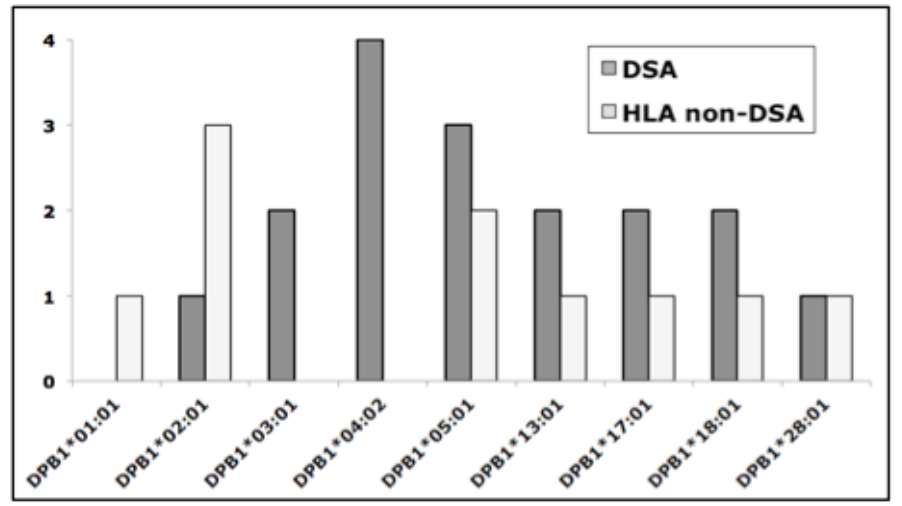

(B)

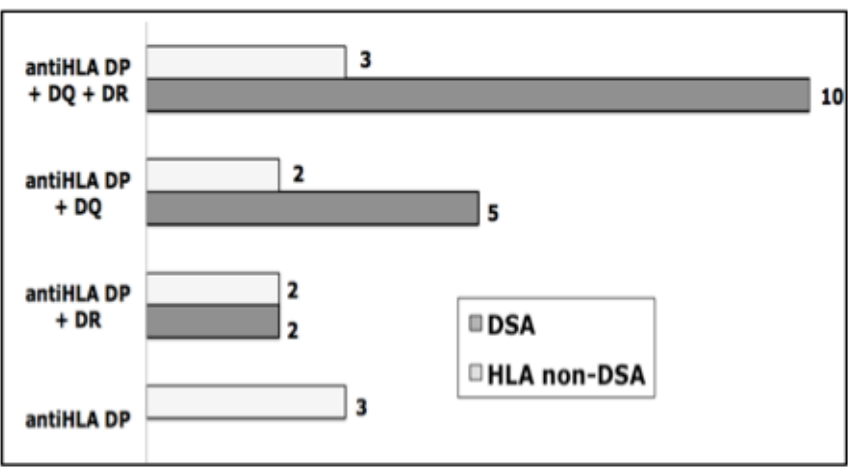


Figure 2

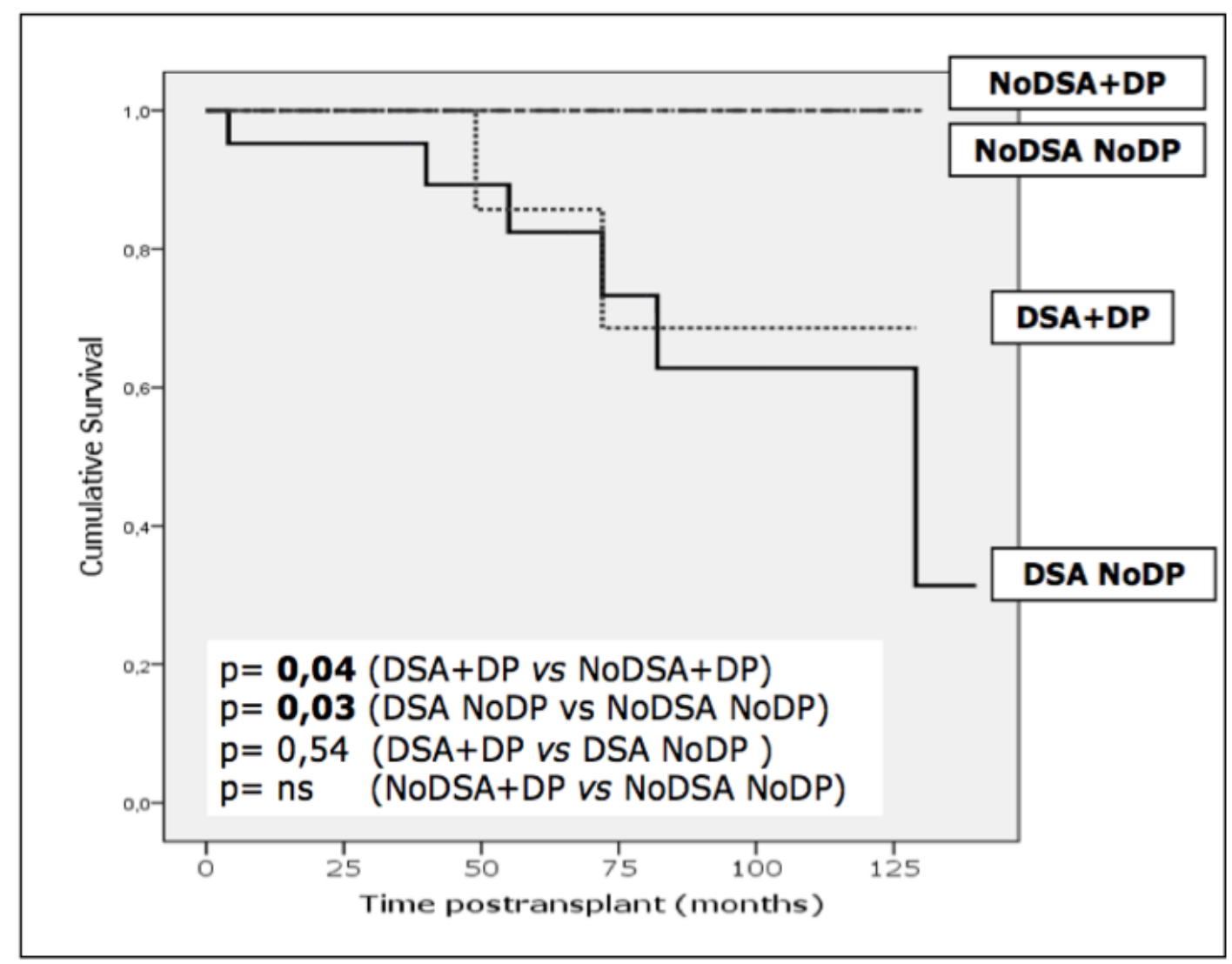


Figure 3

(A)

(B)
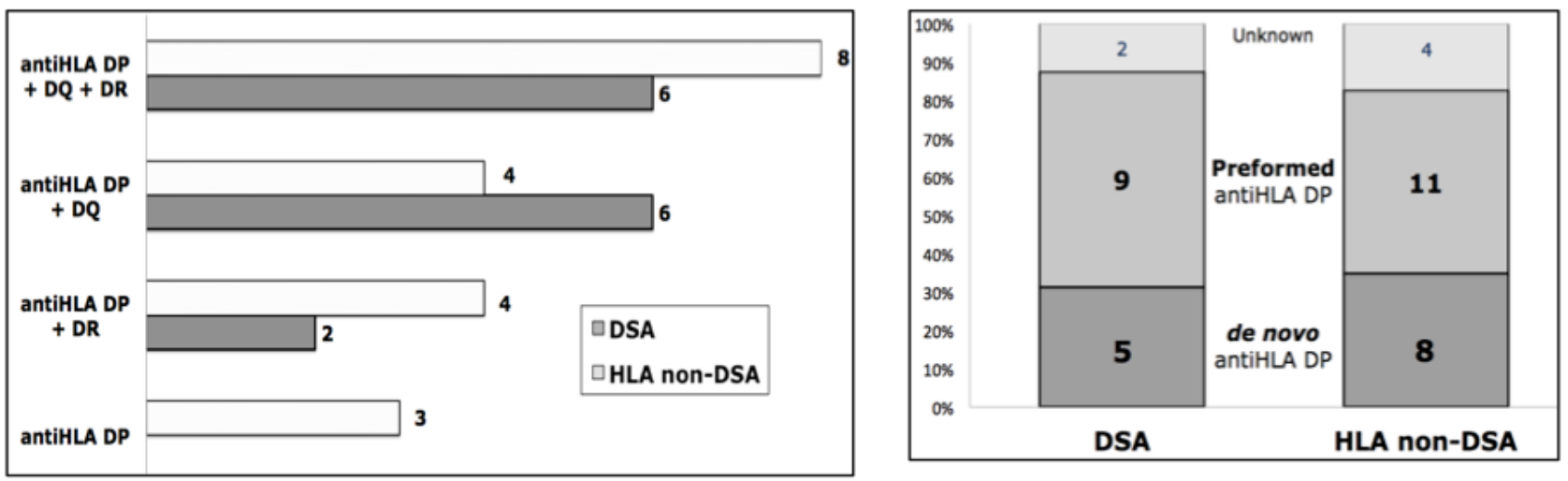
Figure 4

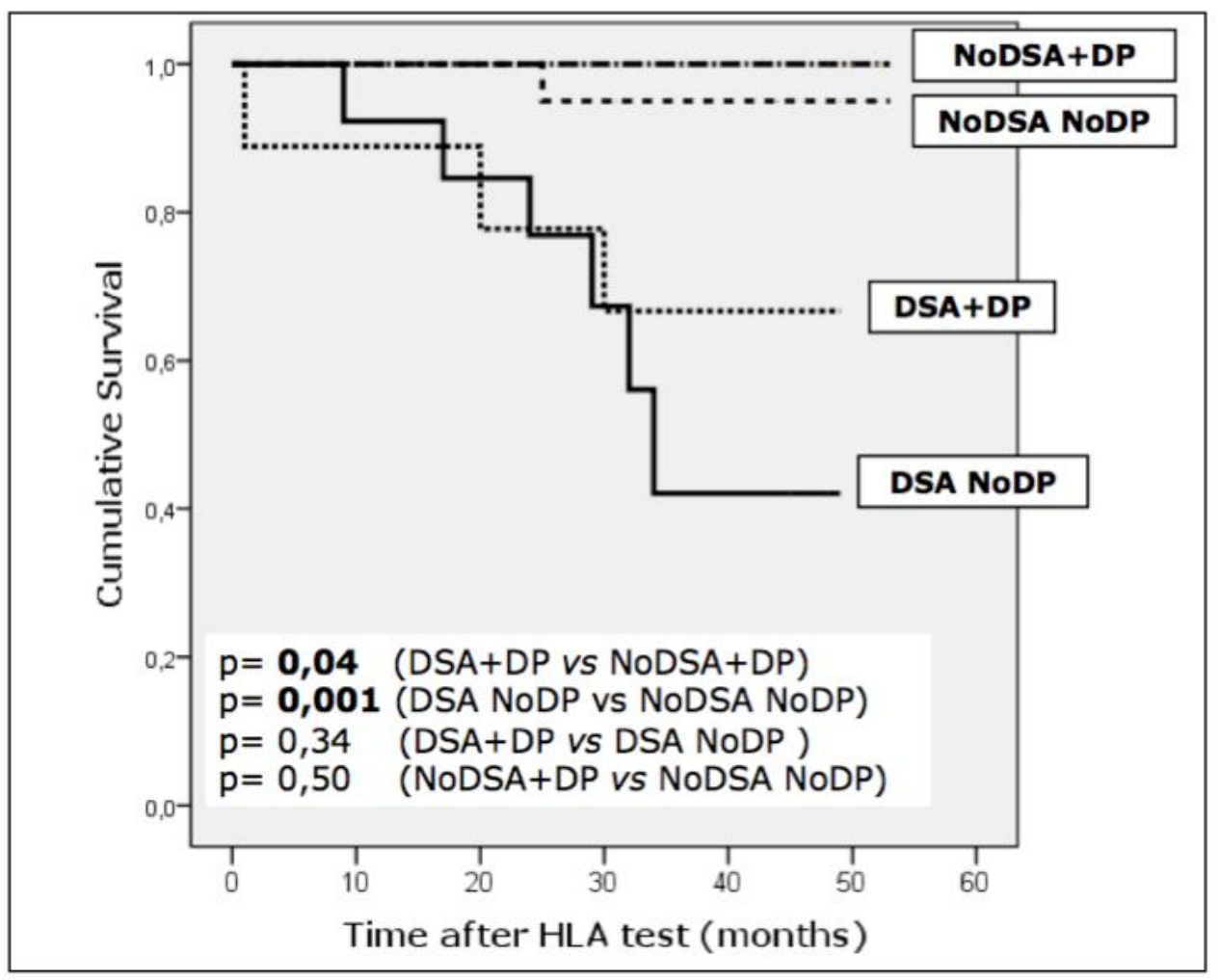

